\title{
Combining Livetext With A Mastery Approach To Meet AACSB Assessment Requirements
}

James A. Spruell, Rockhurst University Craig Sasse, Rockhurst University

\begin{abstract}
Program assessment is an active component of AACSB standards that involves the systematic gathering, analyzing and interpreting of data on degree program effectiveness. The standard ensures that business schools assess degree programs, recommend needed improvements, and implement changes 'that represent contemporary theory and practice.' Livetext is an online suite of tools that permit instructors to actively track and monitor student progress while capturing needed assessment data. In this study we examine the experience at a Midwestern university in implementing Livetext and a 'mastery approach' as vehicles to facilitate course level as well as program and university level assessment. The paper concludes with lessons garnered from the experience.
\end{abstract}

Keywords: AACSB Accreditation, Assessment, Mastery Approach, Livetext

\section{INTRODUCTION}

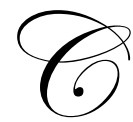

ollege and universities have seen dramatic increases in enrollment over the past 4 decades as students prepare for a complex and turbulent world (Greater Expectations, 2002). Unfortunately, the progress achieved in getting students to college has not been met with equal success in providing every student a quality education. Age old problems continue to surface as educators search for learning centered approaches where the student is the "main agent of learning." (Hewett, 2003). Two of the more serious issues remaining are how to integrate a fragmented curriculum that reflects "a collection of independently owned courses" and a university reward system built upon research, reputation, and resources vs. educational excellence (Greater Expectations, 2002).

The problems have not gone unnoticed by accrediting bodies charged with ensuring that students receive a quality education. Since 2003 the Association to Advance Collegiate Schools of Business (AACSB) International has dramatically increased accreditation standards that require its member schools demonstrate:

C.2.2: Each degree program should be systematically monitored to assess its effectiveness and should be revised to reflect new objectives and to incorporate improvements based on contemporary theory and practice. http://www.aacsb.edu/stand5.html

Central to AACSB standards and philosophy is an insistence that assessment activities focus on degree programs rather than the various majors within a degree (Pringle \& Mitri, 2007; AACSB, 2007). Moreover, faculty members must be actively engaged in that assessment process in providing feedback to students and the university community in the achievement of learning outcomes (AACSB, 2007; Pringle \& Mitri, 2007; Hazeldine \& Munilla, 2004; Martell \& Calderon, 2005). 
The 2003 AACSB shift in standards also provides for direct assessment measures vs. the indirect procedures many programs previously employed. Pringle and Mitri (2007) have pointed out the change is not trivial and represents a paradigm shift that will require extensive, if not traumatic, redesign in assessment tools and methodologies. This shift in standards trails the movement in higher education from a teaching to a learning paradigm (Barr \& Tagg, 1995), and the many calls for radical structural changes within universities so that faculty pursue learning outcomes rather than continuing the focus on teaching inputs (Guskin, 1994).

Fortunately, an important resource for business schools in meeting the new accreditation objectives is the new generation of on-line assessment tools that permit instructors to embed assessment activities within their courses. Course management, assessment, and electronic portfolio (e-portfolio) systems are becoming more prevalent in assisting faculty in managing classroom assessment. In his 2003 survey, Ken Green (2004) reported that about $1 / 3$ of all courses use course management tools with an additional $1 / 8^{\text {th }}$ of all institutions providing e-portfolio services. These numbers are up sharply from previous years and reflect strong adoption among 4-year public institutions vs. community colleges.

Unfortunately, the increased interest and use of instructional technology and resources is unevenly distributed among university faculty. Zayin, et.al. (2006) reported that full implementation of information technology in the classroom is at near saturation among 'early adopters' while mainstream faculty tend to lag considerably behind. The uneven distribution raises some interesting questions for institutions wishing to take advantage of the reporting and assessment tools offered by products such as Livetext. Ken Green in his 2003 survey of campus computing noted that all sectors of higher education continue to identify 'assisting faculty integrate technology into instruction' as the primary IT issue. In Zayin's 2006 study, self-efficacy was identified as a major factor in determining faculty adoption.

Another important aspect of assessment is how improvement is measured: is improvement defined as higher average student scores on program rubrics or conversely by the number of students who have mastered the designated skills and educational goals? The former emphasizes improving average skill levels while the latter focuses on student's demonstrating satisfactory mastery of all essential learning outcomes. In this situation educational excellence is achieved/demonstrated when a specified percent of the students within a program can demonstrate professional competence on core outcome measures.

Mastery concepts are not new, and work on the proposition that students can succeed when given adequate instruction and flexible time in achieving instructional goals (Carroll, 1989). Students are provided clear learning objectives, instruction sometimes in multiple formats, and any number of assignments that reinforce learning outcomes. For example, in computer program/skill level courses the students might receive instruction, immediate practice time to try out the new skills, and assessed by demonstrating the completed program along with answering a few questions by their instructor. Because many computer programming courses require multiple activities to produce a working application, the students must master all topics before going forward. The mastery approach mitigates the probability of a student failing to understand input/output activities that are a pre-requisite to any processing activities.

The recent shift in AACSB program assessment activities and potential requirement for redesign of assessment activities is proving to be somewhat problematic. With that in mind this paper's intent is threefold:

- $\quad$ Present the authors' experience in utilizing an online tool (Livetext) to collect and analyze assessment data;

- $\quad$ The value of using a mastery approach as an educational and assessment philosophy;

- $\quad$ Identify lessons learned in implementing this strategy.

\section{USING AN ELECTRONIC ASSESSMENT SYSTEM: A CASE STUDY}

In the late 1990s our university formed the Center for Teaching Excellence and begin the shift towards more outcomes based teaching and learning. In 2002, the university formally committed to using direct assessment methods such as course-embedded assessment as a primary means for assessment. A key element of course- 
embedded assessment or any direct assessment is the use of learning outcomes that can be measured. Since 2003 the university has used twice-a-year course-embedded assessment workshops that focus faculty on developing measurable learning outcomes for their courses, including creation of rubrics that make measurement possible.

In this context, both authors developed an introduction to business course (BUS 1900) to include writing assignments targeting the development of student writing skill. As an introductory course to the School's business administration degree (BSBA), BUS 1900 offers an ideal context for using a mastery learning approach. Specifically, students were assigned to read selected Wall Street Journal articles, summarize them in one paragraph, and in some cases also add an essay component. Students were assigned 7 of these short papers throughout the semester.

Facilitated by the School of Management's curriculum and assessment committee, the faculty used a common rubric that identified the writing criteria of content, coherence, and copy-editing (shown in table 1). Using a mastery approach, students were measured against this rubric with the mastery goal of achieving at least satisfactory ratings for the criteria on the rubric for student papers.

\begin{tabular}{|c|c|c|c|c|}
\hline Criteria & Exemplary & Satisfactory & & \\
\hline \multirow[t]{2}{*}{ Content } & $\begin{array}{l}\text { The summary identifies the } \\
\text { central theme or thrust of the } \\
\text { article, providing enough } \\
\text { concrete facts to cover points } \\
\text { in the article. }\end{array}$ & $\begin{array}{l}\text { Has a solid topic sentence } \\
\text { that conveys main thrust } \\
\text { but either is too focused } \\
\text { on some tangent or too } \\
\text { cluttered in details. }\end{array}$ & $\begin{array}{l}\text { The main idea is not } \\
\text { clear, inaccurately } \\
\text { depicted, or obscured } \\
\text { by excessive narrative. }\end{array}$ & $\begin{array}{l}\text { Interjects opinion } \\
\text { rather than reporting } \\
\text { on article and } \\
\text { conveys inaccuracies. }\end{array}$ \\
\hline & 5 & 4 & 3.5 & 3 \\
\hline \multirow[t]{2}{*}{ Coherence } & $\begin{array}{l}\text {... sentences are all linked by } \\
\text { explicit transitions. Sentences } \\
\text { are skillfully constructed, } \\
\text { emphatic, effectively varied. }\end{array}$ & $\begin{array}{l}\text { Mostly easy to read, and } \\
\text { sentences are free of } \\
\text { serious clarity, } \\
\text { choppiness, or } \\
\text { awkwardness issues. } \\
\end{array}$ & $\begin{array}{l}\text { Some obvious } \\
\text { sentence issues: } \\
\text { clarity, choppiness, or } \\
\text { awkwardness that } \\
\text { makes reading hard. } \\
\end{array}$ & $\begin{array}{l}\text { Some obvious } \\
\text { sentence issues: } \\
\text { clarity, choppiness, } \\
\text { and awkwardness that } \\
\text { makes reading hard. }\end{array}$ \\
\hline & 3 & 2.5 & 2 & 1 \\
\hline $\begin{array}{l}\text { Copy- } \\
\text { editing }\end{array}$ & $\begin{array}{l}\text { No more than } 1 \text { sentence, } \\
\text { spelling, punctuation, or } \\
\text { grammar errors per } \\
\text { paragraph. Paper has been } \\
\text { proofed to correct typos. }\end{array}$ & $\begin{array}{l}\text { Relatively free of the } 4 \\
\text { types of errors, with the } \\
\text { errors generally not } \\
\text { distracting, but still more } \\
\text { than the exemplary. }\end{array}$ & \multicolumn{2}{|c|}{$\begin{array}{l}\text { The document has enough sentence, } \\
\text { punctuation or spelling errors to distract from } \\
\text { credibility of source or in comprehending the } \\
\text { reading. }\end{array}$} \\
\hline & 2 & 1 & \multicolumn{2}{|c|}{$\mathbf{0}$} \\
\hline
\end{tabular}

In the Spring of 2006, The School of Management started a pilot for implementing LiveText, a proprietary e-portfolio system. With the adoption of LiveText, the school not only saw the potential for enriching student learning experiences through an e-portfolio interface, but the opportunity to more easily collect program assessment data. That is, LiveText allows for embedding rubrics such as the one shown in table 1 and collecting data from these rubrics across courses (in Spring 2007 the School offered 4 sections of the BUS 1900 course). LiveText also has a reporting function that allows faculty or administrators to compile data. The payoff for faculty is that this reporting tool allows for easy analysis of 1) student performance over time, 2) inter-rater reliability across faculty users, and 3) results aiding continuous program improvement.

For the first reporting function, figure 1 shows a report calculated by LiveText for a single instructor's course. This provides a quick check on how students are doing, including the horizontal graph that is under the table. A particularly useful part of the report is that the numbers in the table hotlink to a list of student papers that fell in the category. Importantly, from the list, the instructor can drill down even further to look at either the assessment or the submission by the student. This allows for a simple classroom assessment of student performance. For example, using the data in figure 1, the second author drilled down on all the "Needs Improvement" and "Unacceptable" papers to find out what specifically was cited as the problem. Table 2 organizes the results of this audit of the LiveText report. 
Figure 1: Report output for first paper distribution

Milestone: WSJ Paper \#1

Rubric: Level IV -- Single Paragraph WSJ Summary [Three Evaluated Elements]

\begin{tabular}{|c|c|c|c|c|c|c|c|}
\hline & $\begin{array}{l}\text { Excellent } \\
\text { (3 pts) }\end{array}$ & $\begin{array}{l}\text { Satisfactory } \\
\quad(2 \mathrm{pts})\end{array}$ & $\begin{array}{c}\text { Needs Improvement } \\
\text { (1 pts) }\end{array}$ & $\begin{array}{l}\text { Unacceptable } \\
\text { (0 pts) }\end{array}$ & Mean & Mode & Stdev \\
\hline Content & 1 & $\underline{5}$ & $\underline{9}$ & $\underline{6}$ & 1.05 & 1 & 0.84 \\
\hline Coherence & $\underline{0}$ & $\underline{8}$ & $\underline{11}$ & $\underline{2}$ & 1.29 & 1 & 0.63 \\
\hline Copy Editing & $\underline{5}$ & $\underline{\overline{9}}$ & $\underline{6}$ & $\underline{\overline{1}}$ & 1.86 & 2 & 0.83 \\
\hline
\end{tabular}

MO-ROCK-HSOM.3

Coherence

MO-ROCK-HSOM.6

Copy Editing

\begin{tabular}{|l|l|l|l|}
\hline $8(38 \%)$ & $11(52 \%)$ & $2(9 \%)$ \\
\hline $5(23 \%)$ & $9(42 \%)$ & $6(28 \%)$ & $1(4 \%)$ \\
\hline Excellent & Satisfactory & INeeds Improvement & Unacceptable
\end{tabular}

Table 2: Analysis of the needs improvement papers

\begin{tabular}{|l|c|l|c|}
\hline Content & Frequency & Coherence & Frequency \\
\hline Main idea not clear & 13 & Awkward & 8 \\
\hline Unnecessary clutter & 6 & Choppy & 5 \\
\hline More than one paragraph & 3 & Clarity problems & 7 \\
\hline Opinon offered & 15 & & \\
\hline Incomplete or inaccurate & 2 & & \\
\hline
\end{tabular}

In addition to classroom assessment, the LiveText reporting can easily provide inter-rater reliability tests. The 2007 course noted earlier included four sections taught by four different faculty. Table 2 shows the output of the analysis (again, this is created in a few minutes). Such comparisons are for the sole purpose of solely checking implementation of the rubric_are faculty interpreting and rating each category consistently? Table 3 shows the relative rating of the four faculty teaching the four sections of the Bus 1900 course.

Table 3: Inter-Rater Summary table from LiveText Report (Spring 2007)

\begin{tabular}{|c|c|c|c|c|c|c|}
\hline Content & $\begin{array}{c}\text { Faculty A } \\
1.80\end{array}$ & $\begin{array}{c}\text { Faculty B } \\
2.32\end{array}$ & $\begin{array}{c}\text { Faculty C } \\
1.00\end{array}$ & $\begin{array}{c}\text { Faculty D } \\
2.07\end{array}$ & $\begin{array}{c}\text { Mean } \\
1.80\end{array}$ & $\begin{array}{c}\text { Stdev } \\
0.50\end{array}$ \\
\hline Coherence & 2.40 & 1.57 & 1.29 & 2.52 & 1.94 & 0.53 \\
\hline Copy Editing & 2.80 & 1.71 & 1.76 & 2.59 & 2.22 & 0.48 \\
\hline
\end{tabular}

The inter-rater summary report is useful for faculty interested in continuous improvement. In our School's case, the inter-rater summary was part of a more complete analysis undertaken by our curriculum and assessment committee to review the learning goal of written communication. In fact, the discrepancy among raters indicated that the rubric categories were either poorly defined or not commonly understood in how to apply. This created a discussion among the committee on how we might a) clarify the rubric and/or b) implement it more effectively. We chose to revise the rubric to try and make it clearer (See appendix 2 for the revised rubric) based, in part, on using the LiveText Reports analysis.

\section{REFLECTIONS ON THE USE OF LIVETEXT AND MASTERY LEARNING}

Typically Mastery approaches hold achievement levels constant while permitting greater flexibility in the time allotted for assignment completion (Hewett, 2003). In more traditional environments deadlines tend to be less negotiable with student performance rated within a specified period. The philosophy works reasonably well with 
students who are well prepared, rapid learners, etc. but may leave significant educational gaps for others. For example, the inability to calculate and use percentages may be masked by scoring systems based on averages. A low score in one area is offset by scores in other areas somewhat reminiscent of drowning in water with an average depth of one foot. The problem wasn't the average depth but the significant seven foot hole masked by 'averages.'

Significant educational gaps are simply unacceptable in today's complex and competitive business environment especially when the gaps are unnecessary. Mastery closes many, if not all, of those gaps by beginning with the concept that every student accepted to the university is capable of accomplishing essential learning objectives. While instructional methods may vary, assignments are typically used to reinforce the material prior to assessment. If the instructor deems that progress is not satisfactory then the student is required to correct the assignment before credit is given.

Online assessment tools such as Livetext support both traditional and mastery assessment philosophies. The core strategies selected for implementing assessment with Livetext should reflect what the program/faculty member wishes to accomplish. If the goal is to demonstrate progressive improvement in outcome scores Livetext can produce reports showing average scores on a specific outcome. The difficulty here-in is the inter-rater variability described earlier. Operator/faculty variability may be reduced by appropriate training but may be met with some resistance that reflects underlying core educational values. Longitudinal studies may also be somewhat problematic although a potential solution is to identify faculty to work with a specific outcomes and sample student's performance at targeted intervals. For example, our business school uses Wall Street Journal summaries (and the associated Livetext rubrics) in the freshman and capstone courses to assess business communication skills (See Appendix 1 for a revised common rubric). Longitudinal studies can be used to measure individual and program progression because of Livetext's ability to preserve work products.

On the other hand, if the objective is mastery-based a slightly different implementation is suggested. In this scenario progress is measured by the number of students who have mastered a specified outcome, i.e., the graded rubrics reflect no 'unacceptable' or 'needs improvement' elements. For example, initial assessments in the freshman course (table 1) reflected that barely $40 \%$ of the ratings were at least satisfactory. Further, only 15 percent of students completed the summary assignment without at least one rating as 'needs improvement' or 'unacceptable'. However, by the end of the semester (the $7^{\text {th }}$ paper) a substantially higher percent of students could complete a summary type assignment at the satisfactory level or higher.

Key to successful implementation in the example just mentioned was that two distinct types of feedback were received on work submitted via Livetext. First, Livetext now permits comments to be made directly on submitted text, e.g, this sentence is awkward and needs restructuring. Secondly the assignment is assessed using an appropriate rubric. For the student to receive credit the work product must be free of all 'needs improvement' and 'unsatisfactory' elements. Any work products containing such would need to be corrected and resubmitted. Feedback is relatively immediate with specific corrections to be made identified.

In having used this approach for a number of years with and without online support a few lessons are apparent:

- Students may or may not correct deficiencies reflected in a graded assignment but will rarely (less than 5\% of the time) forgo making corrections when faced with receiving 'no credit' for the work product. Adversarial relationships are unusual since corrections are permitted and even required. When online support is not utilized, verbal feedback works well in simply informing a student that parts $a, b$, and $c$ are acceptable but that for credit part $\mathrm{d}$ must be corrected. Online support does allow progress to be tabulated without further intervention for course and program level assessment.

- $\quad$ Livetext rubrics are specific and directly identify needed improvement, e.g., the ideas lacked concrete support, ergo, if you wish to receive credit, go back and add the essential supporting detail.

- $\quad$ Flexibility is essential with some students doing well in a short amount of time while students who may not have had the same preparation may need more time. The flexibility allows many of the serious gaps or deficiencies to be corrected. 
- $\quad$ Students enjoy 'signing off' and mastering a topic. A sense of accomplishment is gained that she/he is capable of doing a Pivot table, writing a solid essay that supports the main topic with relevant details, or presents information with a solid physical delivery.

\section{IMPLEMENTATION LESSONS}

Experience has provided a number of lessons in combining online assessment tools and Mastery approaches. Two that stand out revolve around putting a complete assessment package together as well as the issues/lessons with implementing any new technology. In the former case, a complete assessment package involves many elements some of which a university might want to implement with a mastery/online tool but others it may not. For example, Appendix 3 shows an assessment overview for one of our courses developed as an Excel spreadsheet. Two of the objectives have been designated as mastery level objectives with data gathered by Livetext. The design purpose is to ensure that in these two areas students master essential skills in evaluating ethical situations and in the basics of business communications. Data gathered can automatically provide the instructor feedback on student progress but the data also can be collated to provide program level feedback.

In this course the instructor's goal was to ensure that every student could meet essential communication skills at a satisfactory level or better for each category. Livetext's role was to provide the online support to assist in removing structural problems in written communication. As such, the rubric was not used as a direct conversion to a specific grade although instructors may elect to do so.

Noteworthy is that traditional grading approaches were also used in quizzes, etc. to distinguish performance at an 'Outstanding level (A)' from 'Above average (B), etc. In cross referencing the learning activities, assessment, etc. gaps are identified as well as areas that the instructor might want to improve upon. The matrix tool does provide for an evaluation of progress made on each learning outcome to help further refine and suggest improvements. In using the spreadsheet matrix instructors occasionally question how are they to know what percent of students have mastered a specific goal ... which is a good indication that the learning outcome was not really being assessed. Redesigning the quizzes, cases, etc. might be necessary to provide students the instructor's feedback.

The second broad implementation issue is that common to most organizations implementing new technology - the need for a change management plan that identifies strategies to overcome user resistance (student and faculty), provide training and support, and resources essential to implementation. To foster user buy-in students and faculty need to hear the message from 2 key elements - top management (a Dean) and their immediate supervisor (Departmental chair). Rewards need to be designed that reinforce usage, adequate training identified for faculty and students, and often a 'burn the bridge' approach initiated to remove any tendency to evade assessment changes.

Similarly licensing fees can be an issue for students. Progress can be facilitated by identifying an initial course where credit for work products is only given if that product is submitted through Livetext. Additionally, honesty is important in controlling student expectations - exaggerated claims about what the application can accomplish should be avoided. Lastly students appear more receptive if they understand that although the licensing fee is incurred as a freshman, other courses will use the product throughout their academic career.

\section{SUMMARY}

Business school education is changing - past practices that focused on input (vs. learner centered), hit-ormiss assessment (now required), and indirect (vs. direct) measures will not meet the new round of business school assessment standards. Many options are available to update program assessment strategies including online course management, e-portfolio, and assessment tools.

As suggested many strategies exist and this paper focused on a Midwestern university's experience in implementing a Mastery-based approach supported by Livetext. The approach proved useful in providing course, 
program, and university level feedback. Data gathered allowed rubrics to be refined, training issues identified, and progress documented.

At the student level the approach provided useful assistance in working with students to directly identify gaps/deficiencies in learning outcomes. The feedback from Livetext supported rubrics allowed students to identify areas on assignments that 'Needs improvement' or 'Unacceptable' and then make those corrections before receiving credit for the assignment. While a pen-and-paper approach could have also been used, the online support allowed assessment data on the outcome to be gathered automatically.

The approach and philosophy is flexible and should be tailored to what the faculty wants to accomplish within a specified outcome. In the author's experience a Livetext supported Mastery approach provided substantial assistance in meeting their instructional goals.

James Spruell: James Spruell, associate Professor, received his MBA and doctorate from the University of Oklahoma. Dr. Spruell has over 25 years of experience in Information Technology, and has served as a featured and invited speaker at a number of regional \& international conferences. He also served as a Department Chair and the advisor for the MBA with an Information System Concentration at the University of Central Missouri before coming to Rockhurst University.

Craig M. Sasse, Ph.D: Craig is Assistant professor of management and division chair at Rockhurst University, Helzberg School of Management. He publishes in the areas of performance management, corporate social responsibility, and pedagogy, including the area of business communication. Among journals his work is published: Business Horizons, Business Case Journal, Annual Advances in Business Cases, and Journal of Business and Leadership. Craig is also a partner in the executive development firm, LeaderPoint, which serves a number of national business clients in managerial leadership development.

\section{REFERENCES}

1. Barr, R. \& Tagg, J. (1995 Nov/Dec). From teaching to learning-A new paradigm for undergraduate education, Change Magazine, 27(6), 13-25.

2. Carroll, J. B. (1989). The Carroll model: A 25 year retrospective and prospective view. Educational Researcher. 18 (1), 26-31.

3. Greater Expectations: A New vision for learning as a nation goes to college. 2002. National Panel Report, Washington, DC: Association of American Colleges and Universities. 2002.

4. Green, Keneth. 2004. Tracking the digital puck into 2004. Retrieved December 12, 2007, from http://www.campus-technology.com/print.asp?ID=8574.

5. Guskin, A. (1994, July/August). Reducing student costs and enhancing student learning. Change, 26 (4), $22-29$.

6. Hazeldine, M. E, \& Manilla, L. S. (2004). The 2003 AACSB accreditation standards and implications for business faculty: A short note. Journal of Education for Business, 80, 29-35.

7. Hewett, Stephenie. 2003. Learner-centered teacher preparation: A mastery of skills. Education 1, 24-30

8. Martell, K., \& Calderon, T. (2005). Assessment in business schools: What it is, where we are, and where we need to go now. In K. Martell \& T. Calderon (Eds.), Assessment of student learning in business schools: Best practices each step of the way (Vol. 1, pp. 1- 26). Tallahassee, FL: Association for Institutional Research.

9. Pringle, C. \& Mitre, M. 2007. Assessment practices in AACSB-accredited business schools. (The Association to Advance Collegiate Schools of Business). Journal of Education for Business: Special Issue on Program Assessment. 82(4) pp202-211

10. Zayim, N., Yildirim, S. \& Saka, O. (2006). Technology adoption of medical faculty in teaching: differentiating factors in adopter categories. Educational Technology \& Society, 9 (2), 213-222. 
APPENDIX 1

REVISED COMMON RUBRIC

\begin{tabular}{|c|c|c|c|c|}
\hline Criteria & Exemplary & Satisfactory & Needs Improvement & Unacceptable \\
\hline Context & $\begin{array}{l}\text { Document meets the } \\
\text { requirements for the } \\
\text { audience in the context } \\
\text { of the assignment } \\
\text { (e.g., provides } \\
\text { appropriate purpose, } \\
\text { citations, is } \\
\text { appropriate length). }\end{array}$ & $\begin{array}{l}\text { Document mostly meets } \\
\text { the requirements for the } \\
\text { audience and states } \\
\text { purpose but not as } \\
\text { effectively as it might. }\end{array}$ & $\begin{array}{l}\text { Does not meet one basic } \\
\text { audience/ context } \\
\text { requirement (e.g., wrong } \\
\text { length, no purpose evident, } \\
\text { no introduction, citations } \\
\text { errors). }\end{array}$ & $\begin{array}{l}\text { No context is } \\
\text { established or another } \\
\text { serious error that } \\
\text { confuses whole } \\
\text { document (e.g., writes } \\
\text { wrong type of } \\
\text { message). }\end{array}$ \\
\hline Organization & $\begin{array}{l}\text { Central ideas (or main } \\
\text { points) are clearly } \\
\text { evident (document or } \\
\text { paragraph level), and } \\
\text { provides enough } \\
\text { concrete support for } \\
\text { these main points. }\end{array}$ & $\begin{array}{l}\text { Paragraphs have solid topic } \\
\text { sentences that convey main } \\
\text { point but paragraphs are } \\
\text { either too focused on some } \\
\text { tangent (cluttered in } \\
\text { details) or overly broad } \\
\text { and general. }\end{array}$ & $\begin{array}{l}\text { Main ideas are unclear or of } \\
\text { only tangential relation to } \\
\text { the topic or purpose and/or } \\
\text { obscured by excessive } \\
\text { narrative. }\end{array}$ & $\begin{array}{l}\text { Main ideas are unclear } \\
\text { and details are } \\
\text { unrelated to bigger } \\
\text { points (e.g., } \\
\text { paragraphs lack any } \\
\text { focus). }\end{array}$ \\
\hline Coherence & $\begin{array}{l}\text { Sentences are all } \\
\text { linked by explicit } \\
\text { transitions. Sentences } \\
\text { are skillfully } \\
\text { constructed, emphatic, } \\
\text { effectively varied. }\end{array}$ & $\begin{array}{l}\text { Mostly easy to read, and } \\
\text { sentences are free of } \\
\text { serious clarity, choppiness, } \\
\text { or awkwardness issues. }\end{array}$ & $\begin{array}{l}\text { Some obvious sentence } \\
\text { issues: clarity, choppiness, } \\
\text { or awkwardness that makes } \\
\text { reading hard. }\end{array}$ & $\begin{array}{l}\text { Some obvious } \\
\text { sentence issues: } \\
\text { clarity, choppiness, } \\
\text { and awkwardness that } \\
\text { makes reading hard. }\end{array}$ \\
\hline Copy-editing & $\begin{array}{l}\text { No more than } 1 \\
\text { sentence, spelling, } \\
\text { punctuation, or } \\
\text { grammar errors per } \\
\text { paragraph. Paper has } \\
\text { been proofed to } \\
\text { correct typos. }\end{array}$ & $\begin{array}{l}\text { Relatively free of the } 4 \\
\text { types of errors, with the } \\
\text { errors generally not } \\
\text { distracting, but still more } \\
\text { than the exemplary. }\end{array}$ & \multicolumn{2}{|c|}{$\begin{array}{l}\text { The document has enough sentence, punctuation or } \\
\text { spelling errors to distract from credibility of source or } \\
\text { in comprehending the reading. }\end{array}$} \\
\hline
\end{tabular}


APPENDIX 2

SAMPLE LIVETEXT RUBRIC INCLUDING SUPPORT AND ANALYSIS ELEMENTS.

\begin{tabular}{|c|c|c|c|}
\hline \multicolumn{4}{|c|}{ Writing Rubric } \\
\hline Analysis & $\begin{array}{l}\text { Explores relevant issues related to } \\
\text { the topic, makes reasonable analytic } \\
\text { claims, and uses business terms } \\
\text { correctly. Shows a mind at work } \\
\text { employing creative thinking. }\end{array}$ & $\begin{array}{l}\text { Explores relevant issues related } \\
\text { to the topic, makes reasonable } \\
\text { analytic claims and uses } \\
\text { business terms correctly. }\end{array}$ & $\begin{array}{l}\text { Ideas are shallow and reflect } \\
\text { superficial thinking. }\end{array}$ \\
\hline & 4 & 3.5 & 2.5 \\
\hline Unity & $\begin{array}{l}\text { Paragraphs (or main points) are } \\
\text { clearly unified. The main points are } \\
\text { clear, precise, and meaningful. }\end{array}$ & $\begin{array}{l}\text { While paragraphs tend to be } \\
\text { unified, the main points could } \\
\text { be clearer or assertions more } \\
\text { significant. }\end{array}$ & $\begin{array}{l}\text { Paragraphs tend to be weak with no } \\
\text { apparent main point. }\end{array}$ \\
\hline & 4 & 3.5 & 2.5 \\
\hline Support & $\begin{array}{l}\text { Ideas are supported with concrete, } \\
\text { substantive, and relevant detail }\end{array}$ & $\begin{array}{l}\text { Ideas supported w/ concrete } \\
\text { detail that occasionally may be } \\
\text { repetitious, irrelevant or vague. }\end{array}$ & $\begin{array}{l}\text { Central and subordinate ideas of } \\
\text { various paragraphs lack } \\
\text { concrete supporting data (e.g., no } \\
\text { examples used). }\end{array}$ \\
\hline & 3 & 2.5 & 2 \\
\hline Coherence & $\begin{array}{l}\text { Easy to Read. Sentences are linked } \\
\text { by explicit transitions. Sentences } \\
\text { are skillfully constructed \& } \\
\text { effectively varied. }\end{array}$ & $\begin{array}{l}\text { Mostly easy to read. Sentences } \\
\text { are free of serious clarity, } \\
\text { choppiness, or awkwardness } \\
\text { issues. }\end{array}$ & $\begin{array}{l}\text { Some obvious sentence issues: } \\
\text { clarity (vague meanings or poor } \\
\text { word choices), choppiness, or } \\
\text { awkwardness that makes reading } \\
\text { difficult. }\end{array}$ \\
\hline & 3 & 2.5 & 1.5 \\
\hline $\begin{array}{l}\text { Copy- } \\
\text { editing }\end{array}$ & $\begin{array}{l}\text { No sentence, spelling, punctuation, } \\
\text { or grammar errors. Paper has been } \\
\text { proofed to correct typos. }\end{array}$ & $\begin{array}{l}\text { Relatively free of the } 4 \text { types of } \\
\text { errors: the errors generally not } \\
\text { distracting. }\end{array}$ & $\begin{array}{l}\text { The document has enough sentence, } \\
\text { punctuation or spelling errors to } \\
\text { distract from credibility of source or } \\
\text { in comprehending reading. }\end{array}$ \\
\hline & 3 & 2 & 0 \\
\hline
\end{tabular}


APPENDIX 3

SAMPLE MATRIX DEMONSTRATING MIX OF EDUCATIONAL ACTIVITIES, ASSESSMENT TOOLS, ETC

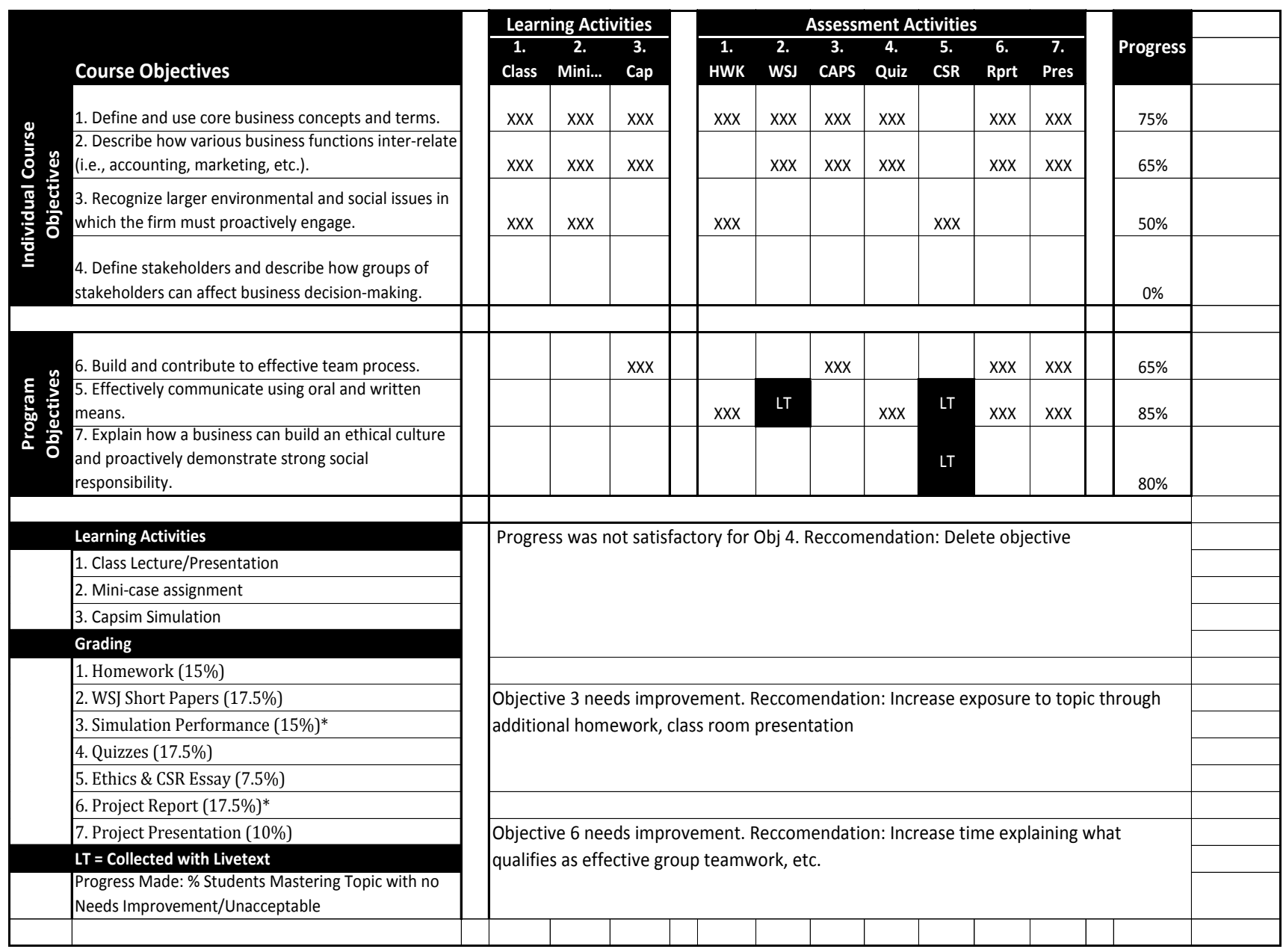

